\section{Founders' feast}

\author{
Ralph A. Lewin
}

Handbook of Protoctista. Edited by Lynn Margulis, John O. Corliss, Michael Melkonian and David J. Chapman. Jones and Bartlett: 1990. Pp. 1,024. \$195. Distributed in the United Kingdom by Van Nostrand Reinhold, £195.

IF I had written this review in Esperanto - a perferctly phonetic international language, much more logical in construction than English - I doubt whether very many readers of Nature would understand it. Verbal communication entails a common understanding of words used by the writer for the readers. If a word means one thing to the writer and something different to the reader, then understanding is impaired. Now consider the terminology of this great book: does it help or hinder understanding? The title, for instance: what are the Protoctista? They are, literally, the founding fathers: proto= first + ctistes $=$ founders. (Note that the accent goes on the ctist, not on the toc.) The word, according to the senior editor, was coined by a Scot, J. Hogg, in 1861, and disinterred by Corliss and Margulis in recent years. Margulis suggests that protoctistologists should now secede from
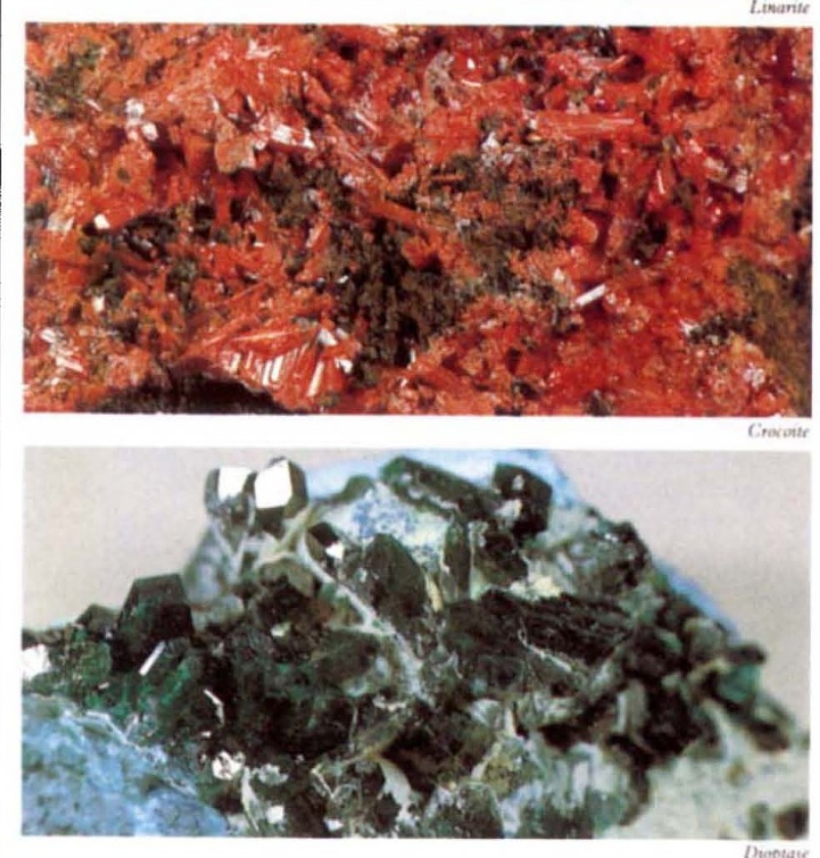

Linarite, Crocoite and Dioptase are just three of the minerals studied in Rocks, Minerals and Fossils of the World by C. Pellant. Minerals are shown mostly as typical specimen material rather than perfect museum exhibits, thereby aiding potential matching of samples. Each mineral that is represented is accompanied by a full description of its properties and some indication of its distribution, together with notes on its more unusual modes of occurrence. Rocks are divided into three sections: igneous, metamorphic and sedimentary, with 'field' photographs illustrating the relationship between strata and rock content. Fossils are arranged in biological groups and stratigraphically. The volume is beautifully illustrated by the photography of R. Phillips and C. Pellant. Published by Pan Books, price $£ 12.99$. Distributed in the United States by Little Brown, $\$ 29.95$. those of bacteria. (By the same reasoning, we should use different words for the wings of birds and insects which, though both are organs of flight, differ fundamentally in size, embryological origin and construction.) The word undulipodia (I assume in Cyrillic) was used in a Russian text, Margulis tells us, by A. P. Shmagina in 1948; it has been transliterated and used by at least two of this book's editors.

Personally, I prefer the term "enneanema", which is more euphonious, uniformly Greek in origin, and reminds one of the nine-stranded construction characteristic of these organelles, rather than suggesting that they are undulant (which some are not) feet (which they certainly aren't). For Margulis, undulipodia are intracellular (because they are inside a membrane), whereas the flagella of bacteria and the axial fibrils of spirochaetes are extracellular (because they are outside the inner plasma membrane).

Not everyone would agree with such distinctions. Our old schoolfriend Spirogyra, in this treatise, is not a Chlorophyte, nor is Saprolegnia, which tends to infest fishes in our home aquaria, a fungus. (The kingdom of fungi is outside the realm of this treatise.) It's all likely to be very confusing. Margulis, like Humpty Dumpty in "Alice in Wonderland", wants words to mean what she decrees for them, whereas I prefer to use words that are, as far as possible, immutably understandable.

There is a more serious element to my critical comments. We are experiencing, in these days of blooming molecular biology, radical revisions of our knowledge of phylogeny, particularly as we become aware of anastomoses among the branches. (Margulis, stating that "all protoctists descend from tightly knit bacterial communities", refers to growing evidence that plastids and mitochondria had symbiotic prokaryotic ancestors.) Nucleotide sequences, and hence aminoacid sequences, are enabling us to construct phylogenetic trees that are, we trust, increasingly objective indications of the pathways of evolution, and our taxonomies will ultimately have to recognize the results of these new disciplines. Just as it has been said that translations of poetry are like mistresses - they can be either beautiful or true, but rarely both - so classifications can be based either on molecular-biology phylogenies, or on human convenience, though these may not be reconcilable. Personally, as we have to put specimens into cabinets and relevant information into chapters, I lean conservatively towards convenience at the present time. Paramecium may be, in margulese, an undulipodiated protoctist, but for me it remains simply a ciliate.

Margulis' real forte is evident in the conceiving and organizing of this, the first encyclopaedic volume to embrace algae, aquatic fungi and protozoa. It has been 